\title{
Combination of biocontrol bacteria for rice seeds microbiolization: incidence and transmission of Bipolaris oryzae, and plant growth ${ }^{1}$
}

\author{
Andréa Bittencourt Moura ${ }^{2 *}$, Aline Garske Santos ${ }^{2}$, Cândida Renata Jacobsen de \\ Farias $^{2}$, Juliane Ludwig ${ }^{3}$, Bianca Obes Corrêa ${ }^{2,4}$, Vanessa Nogueira Soares ${ }^{5}$
}

\begin{abstract}
Several fungi species are associated with rice seeds, mainly Bipolaris oryzae, since it can kill seedlings and reduce production. Thus, the objective of this research was to study the potential of pre-selected combinations of rhizobacteria [DFs-C4 (DFs185/DFs416/DFs418) and DFs-C5 (DFs306/DFs416/DFs418)], when compared to their use individually (DFs185, DFs306, DFs416, DFs418), besides DFs223, evaluating the effect on the incidence and transmission of B. oryzae, incidence of phytopathogenic fungi and in the initial growth after rice seeds microbiolization. Seeds of cultivars BRS Pelota and BRS Querência (four lots each) were immersed in suspension of these bacteria or in saline solution (control) under agitation (for 30 minutes at $10^{\circ} \mathrm{C}$ ). The fungi incidence was evaluated on blotter test. The pathogen transmission was assayed in sterilized vermiculite and humid chamber at $25 \pm 2{ }^{\circ} \mathrm{C}$. After 15 days, the severity of the symptoms and the plant growth were evaluated. For both cultivars, the best treatments were DFs185 and DFs306, reducing the fungi incidence, including $B$. oryzae, as well as its transmission to seedlings, resulting in seedling length increase. The combination of biocontrol bacteria, individually efficient, did not result in a lower fungi incidence, or a reduction in the transmission of $B$. oryzae to the seedlings or an initial increase in seedling growth. Therefore, these rhizobacteria are more efficient when used individually.
\end{abstract}

Index terms: biological control, brown spot of rice, PGPR.

\section{Combinação de bactérias biocontroladoras para microbiolização de sementes de arroz: efeito na incidência, transmissão de Bipolaris oryzae e crescimento vegetal}

\begin{abstract}
RESUMO - Várias espécies fúngicas estão associadas às sementes de arroz, destacando-se Bipolaris oryzae, por causar a morte de plântulas e redução da produção. Assim, o objetivo do trabalho foi estudar o potencial de combinações de rizobactérias pré-selecionadas [DFs-C4 (DFs185/DFs416/DFs418) e DFs-C5 (DFs306/DFs416/DFs418)], quando comparado ao uso destas de forma individual (DFs185, DFs306, DFs416, DFs418), além de DFs223, avaliando o efeito na incidência e transmissão de B. oryzae, incidência de fungos fitopatogênicos e no crescimento inicial das plântulas após a microbiolização das sementes de arroz. Sementes das cultivares BRS Pelota e BRS Querência (quatro lotes cada) foram imersas em suspensão dessas bactérias ou em solução salina (testemunha) sob agitação $\left(30\right.$ minutos a $\left.10^{\circ} \mathrm{C}\right)$. Foi avaliada a incidência de fungos em papel filtro e a transmissão do patógeno em vermiculita esterilizada e câmara úmida a $25 \pm 2{ }^{\circ} \mathrm{C}$. Após 15 dias foram avaliados a severidade dos sintomas e o crescimento vegetal. Para as duas cultivares, os melhores tratamentos foram DFs 185 e DFs306, reduzindo a incidência de fungos, incluindo B. oryzae, assim como a transmissão desse patógeno para plântulas, resultando em aumento no comprimento de plântulas. A combinação de bactérias biocontroladoras, eficientes individualmente, não resultou em menor incidência de fungos, nem redução da transmissão de $B$. oryzae para as plântulas ou em aumento do crescimento inicial de plântulas. Portanto, estas rizobactérias são mais eficientes quando utilizadas individualmente.
\end{abstract}

Termos para indexação: controle biológico, mancha parda do arroz, PGPR.

${ }^{1}$ Submitted on 03/15/2018. Accepted for publication on 08/03/2018. ${ }^{2}$ Departamento de Fitossanidade, Universidade Federal de Pelotas, 96010-970 Pelotas, RS, Brasil.

${ }^{3}$ Universidade Federal da Fronteira Sul, 97900-000 - Cerro Largo, RS, Brasil. ${ }^{4}$ Faculdade de Agronomia Anhanguera, Uniderp, 79037-280 - Campo Grande, MS, Brasil.
${ }^{5}$ Departamento de Fitotecnia, Universidade Federal de Pelotas, 96010-970 Pelotas, RS, Brasil.

*Corresponding author <abmoura@ufpel.edu.br> 


\section{Introduction}

Brazil is among the main rice producers (Oryza sativa L.) in the world. It also stands out in terms of consumption. For the 2014/2015 crop in Brazil, approximately 2.3 million of rice hectares were grown, and the state of Rio Grande do Sul (RS) stood out as the main producer. In that state alone, approximately $1,100,000$ hectares were farmed, and the production exceeded 8 million tons (CONAB, 2014).

The farming of flooded rice is subject to diseases caused by different pathogens, among bacteria, fungi, nematodes and virus, which, by attacking the culture, cause productivity loses. Fungi are the main group of pathogens associated to seeds, and they may lead to production loses and interfere in the physiological quality of the seeds. Among the several diseases transmitted by seeds that occur in the rice culture, the main one is brown spot, due to its ability to cause damages to the culture (Farias et al., 2011). The etiological agent of the disease is the Bipolaris oryzae fungus. The fungus (B. oryzae) may cause damages during germination, such as death of the seeds and seedlings, weakening of adult plants, increased sterility and reduction of the grain quality (Ludwig et al., 2009). The pathogen is also one of the main fungi to cause seed discoloration, reducing their commercial value (Schwanck et al., 2015).

Seeds with pathogens represent one of the main causes for their dissemination and transmission, since epidemies may begin from the germination of the seeds, which will produce seedlings with symptoms of the disease. With the plant development, the pathogen is also disseminated, contaminating other plants and producing infected seeds, which will be the means of dissemination to new areas or the initial inoculum over the following crop (APS, 2015).

To control the brown spot disease, integrated management techniques are used, mainly through the use of resistant cultivars, which is an efficient and low-cost measure. However, the lifetime of resistant cultivars may be reduced due to the adaptation of the pathogen populations (Nunes et al., 2004). Treating the seeds with fungicides is a preventive treatment alternative, since several pathogens are carried by the seeds; however, they may cause environmental problems and the selection of resistant pathogen populations (Chandler et al., 2011).

Considering that fact, biological control is an alternative to control diseases, allowing the reduction, or even elimination of the use of pesticides, contributing to reduce the environmental damages and production costs. The positive aspects of this method are its low cost and environmentally friendly; however, unlike chemical control, it is rarely spectacular (Bettiol and Morandi, 2009), since, in many cases, the results are not stable in the field scale. As an alternative to overcome such limitation, the strategy of using combinations of efficient biocontrols has been adopted (Xu et al., 2011), usually increasing the stability and the action spectrum, since it aggregates different mechanisms of action, such as competition, parasitism, predation, antibiosis and induced systemic resistance (Bettiol and Morandi, 2009).

In Brazil, the Research Group "Biocontrol Bacteria for Plant Diseases that promote Plant Growth" from the Universidade Federal de Pelotas (UFPel) selected rhizobacteria with the potential to control B. oryzae and Gerlachia oryzae (Ludwig et al., 2009), Rhizoctonia solani (Souza-Júnior et al., 2010), Pyricularia grisea (Souza-Júnior et al., 2017) and Meloidogyne graminicola (Ludwig et al., 2013). However, these studies evaluated the ability of the treatment of seeds with rhizobacteria to reduce pathogens inoculated in young plants. Recently, Moura et al. (2014) showed that rice seeds microbiolized with such bacteria also reduced the transmission of B. oryzae and G. oryzae from naturally infested/infected seeds to seedlings. However, little is known about the impact of using combinations of biocontrols on the transmission of pathogens on the seeds.

Several biocontrol bacteria are able to colonize the root system of plants, and, in that case, they are called rhizobacteria. This group of bacteria is known for its ability to produce compounds associated to the biocontrol of plant diseases and to growth promotion. Thus, they may act through biocontrol mechanisms (indirect growth promotion), such as by inducing the systemic resistance on plants, through competition, producing siderophores, through the production of antibiotics and enzymes associated to the parasitism of phytopathogens; as well as directly, through growth promotion, such as, for example, through the biological fixation of nitrogen, synthesis of siderophores, production of phytohormones, phosphorus solubilization and acceleration of the mineralization processes (Ahemad and Kibret, 2014).

Thus, the objective of this research was to study the potential of rhizobacteria combinations, when compared to their individual use, evaluating the effect on the incidence and transmission of $B$. oryzae, the incidence of phytopathogenic fungi and plant growth promotion after the microbiolization of the seeds from four lots of two rice cultivars.

\section{Material and Methods}

\section{Cultivars and rice seed lots used for the assays}

For all assays, seeds from two rice cultivars were used: BRS Pelota and BRS Querência. The first one is moderately resistant (SOSBAI, 2012) and the second one, moderately 
susceptible (Fagundes et al., 2005) to brown spot disease. Samples from four lots of seeds from each cultivar were used, selected to have the same origin and sowing time (crops from the municipality of Pelotas, sown in the same week) and similar level of $B$. oryzae natural infection/infestation, determined by the blotter test (Brasil, 2009a). The work samples were obtained according to the Rules for Seed Testing (Brasil, 2009b).

\section{Treatments used}

The treatments used were the following combinations DFs-C4 (DFs185/DFs416/DFs418) and DFs-C5 (DFs306/ DFs416/DFs418), previously selected by Souza-Júnior et al. $(2010,2017)$. For comparison purposes, the bacteria that constitute each combination were also used individually: DFs185 (Pseudomonas synxantha), DFs306 (non-identified), DFs416 and DFs418 (Bacillus sp.), in addition to DFs223 (P. fluorescens), which, due to its incompatibility with the other bacteria, was not used in combination.

\section{Microbiolization of rice seeds}

The bacterial suspensions were prepared in saline solution $(\mathrm{NaCl} 0.85 \%)$ after $24 \mathrm{~h}$ of growth in 523 medium (Alfenas and Mafia, 2016). Each suspension was adjusted for optical density corresponding to $10^{8}$ colony-forming units. The combinations were constituted by a mix of equal volumes of suspension from each one of the bacteria prepared separately.

Seeds were immersed in bacterial suspensions and agitated for 30 minutes at $10{ }^{\circ} \mathrm{C}$. The control treatment was constituted by seeds immersed only in saline solution.

Incidence of Bipolaris oryzae and other fungi after microbiolization of rice seeds with rhizobacteria

Microbiolized seeds, as described above, were planted in gerbox ${ }^{\circledR}$ according to the blotter test (Brasil, 2009a) and taken to the incubation room at temperature of $25 \pm 2{ }^{\circ} \mathrm{C}$ and photoperiod of $12 \mathrm{~h}$ for seven days when they were individually evaluated in a stereoscopic microscope. The incidence of $B$. oryzae was evaluated, and it was identified observing the characteristics of the conidia and conidiophores on an optical microscope and compared to the specialized literature, similarly as conducted by Farias et al. (2011). The other incident fungi were morphologically identified and grouped as seed discolorating and non-discolorating, according to Moura et al. (2014). Then, the incidence percentage was calculated in relation to the control treatment, considered as $100 \%$.
Impact of microbiolization of rice seeds with rhizobacteria on the transmission of Bipolaris oryzae and initial seedling growth

The seeds were microbiolized and individually placed in $110 \mathrm{~mL}$ plastic cups containing sterilized vermiculite, which were then placed in transparent plastic boxes. Each box containing 24 cups constituted one plot, maintained in a humid chamber and incubated in a room with temperature at $25 \pm 2{ }^{\circ} \mathrm{C}$ and photoperiod of $12 \mathrm{~h}$. The experimental design used was the randomized blocks design, in triple factorial: 2 cultivars, 4 lots of each cultivar, 8 treatments ( 7 bacterial treatments and 1 with saline solution), with three replications.

After 15 days of incubation, an individual evaluation of each seedling was conducted, and, according to the symptom shown, grades were assigned as described as follows: 0seedlings without any symptoms; 1- seedlings with typical lesions on the leaves; 2- seedlings with typical lesions on the coleoptile; 3- seedlings with typical lesions on the coleoptile and leaves; 4- post-emergence death and; 5- pre-emergence death. Non-germinated seeds were removed from the substrate and washed in running water and then in sterilized water and submitted to humid chamber in order to confirm the presence of $B$. oryzae in the seed. The values obtained from the grade scale were used to calculate the disease index (DI), according to the formula suggested by Mc Kinney (Alfenas and Mafia, 2016).

Then, the shoot and the root system of the seedlings were separated in order to measure the length of both parts. They were placed in an oven $\left(60^{\circ} \mathrm{C}\right)$ with air circulation until they reached constant weight. Then, the dry mass of the parts was evaluated.

\section{Statistical analyses}

The data obtained from the B. oryzae transmission and initial growth testes were submitted to variance analysis, and the means were compared using Tukey's test at 5\% of error probability, using the statistical program Assistat Version 7.6 beta (pt).

\section{Results and Discussion}

The impact of the bacterial seed treatment to control different fungi, evaluated by the blotter test, was different according to the studied fungus or group of fungi and the different lots for both cultivars used.

In the evaluation of the incidence of $B$. oryzae in seeds from cultivar BRS Pelota (Figure 1), it was possible to observe that, except for lot 2 , the bacterial treatments efficiently reduced the incidence of the pathogen. For lot 1, the most efficient treatments were DFs418, DFs306 and DFs185; the DFs-C4 combination was the best one for lot 2; DFs306 and DFs416 stood out for lot 3, and for the last evaluated lot, i.e., lot 4, the 
most efficient treatments were DFs306 and DFs418. Although the efficiency of the treatments varied for the different lots, treatment DFs306 stood out three times, resulting in a better performance considering the general average of the lots, when it reduced the incidence of the pathogen in $42 \%$.

For cultivar BRS Querência, it was possible to observe that for all lots and treatments, the incidence of the pathogen was reduced after the microbiolization of the seeds (Figure
1B). For that cultivar, a regular behavior was observed for the treatments, emphasizing DFs185 and the DFs-C4 combination as the most efficient ones for lots 1, 2 and 4, and as intermediate for lot 3 . Such stability affected the general average of the lots, when the treatments reduced up to $42 \%$ (DFs185) and 38\% (DFs-C4). The other treatment that stood out individually was DFs306 on lot 3 , with an intermediate behavior regarding the lots average.

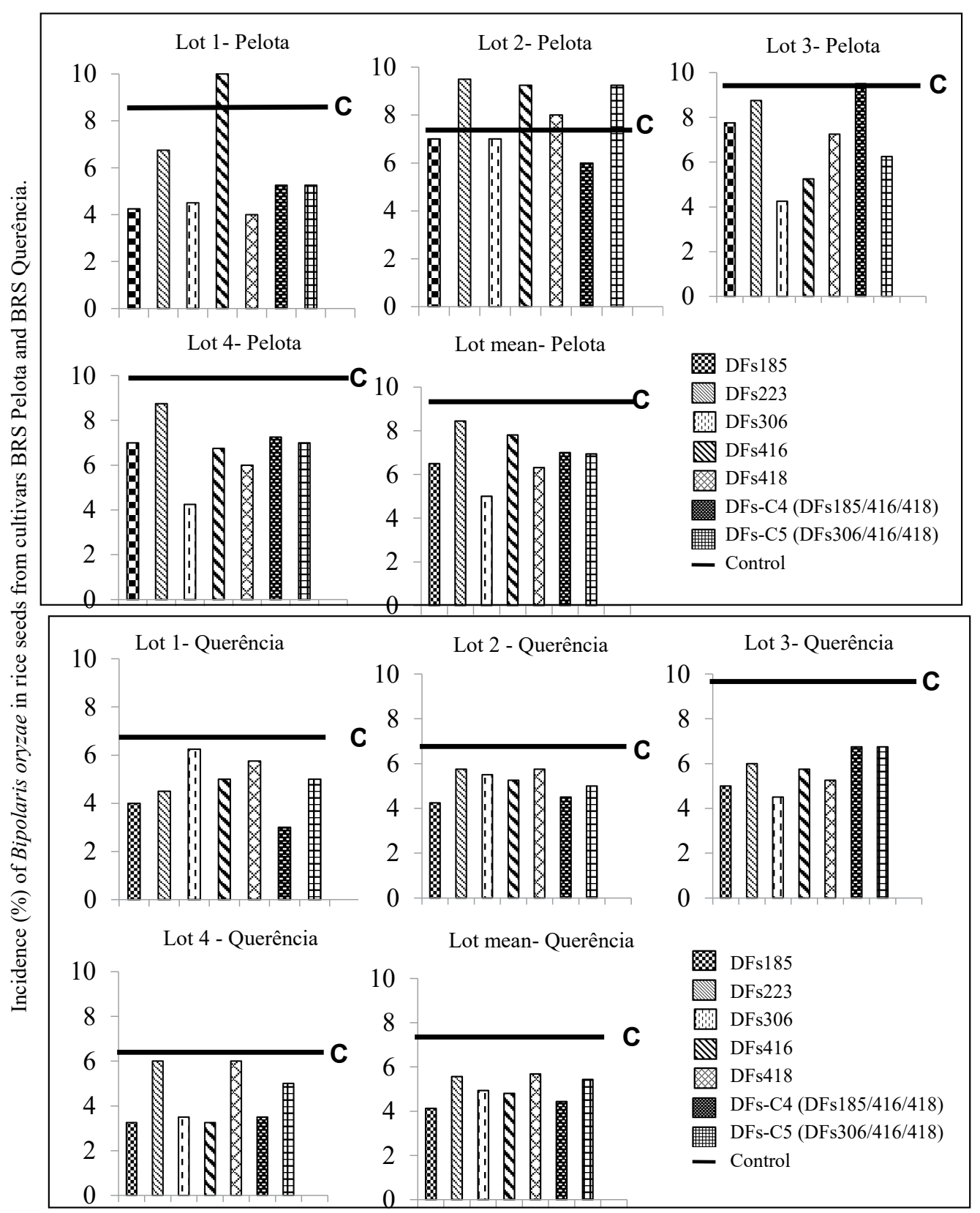

Figure 1. Incidence (\%) of Bipolaris oryzae in rice seeds from cultivars BRS Pelota and BRS Querência after microbiolization with rhizobacteria DFs185 (Pseudomonas synxantha), DFs223 (P. fluorescens), DFs 306 (non-identified), DFs416 and DFs418 (Bacillus sp.) and combinations DFs-C4 (185/416/418) and DFs-C5 (306/416/418) using the blotter test method. Control (C) considered as $100 \%$. 
In general, the incidence of $B$. oryzae was higher for the lots of cultivar BRS Pelota (8.7\%) than for the lots of cultivar BRS Querência (7.2\%); however, the survival rate reduction was higher for the lots from cultivar BRS Querência (30.5\% against $21 \%$ for cultivar BRS Pelota).

On the other hand, the mean reduction on the incidence of B. oryzae on the different lots, considering both cultivars, showed no significant variation (33.29 to $30.71 \%$ ), except for lot 2 of cultivar BRS Pelota (11.19\%), although this lot showed lower control values than the average for each cultivar.

The incidence of other phytopathogenic fungi was also observed, grouped by Moura et al. (2014) associated to seed discoloration: Alternaria spp., Curvularia spp., Gerlachia spp., Phoma spp. and Pirycularia spp.; and non-associated to seed discoloration: Acremonela spp., Aspergillus spp., Cladosporium spp., Epiccocum spp., Fusarium spp., Nigrospora spp., Penicillium spp., Rhizopus spp., and Trichoderma spp.

The effect of the different bacterial treatment on the incidence of fungi associated and non-associated to seed discoloration varied significantly on the different lots of cultivar BRS Pelota (Figure 2). Such variation could be observed by the means of the lots, showing that, for fungi associated to discoloration, the DFs-C5 combination stood out separately, with a reduction of $38 \%$ on the fungi incidence for this group, followed by the treatments with DFs 185 , DFs306, DFs 416 and DFs418 individually, which showed an intermediate behavior (reduction of 15 to $20 \%$ ). For non- fungi associated to discoloration, an expressive effect occurred only on lot 4 for all treatments (varying from $44 \%$ to $14 \%$ of incidence reduction), for DFs185 on lot 1 (reduction of 30\%) and for DFs223, DFs416 and DFs-C4 on lot 2. Thus, considering the mean for the lots, the treatments with lower incidence were DFs 185 and DFs416 (similar reductions, close to $15 \%$ ).

When the incidence values of other fungi are observed on the lots of cultivar BRS Querência (Figure 2), it is observed that, in general, combinations stood out as to the reduction of fungi associated to seed discoloration for all lots, while treatment DFs 185 stood out only for lot 1 , and DFs 306 , for lot 3 . In relation to fungi non associated to seed discoloration, the effect of the treatments had little variation considering each lot. Most of the times, the individual treatments stood out: DFs 185 for lots 2 and 3; and DFs416 for lot 4; while for lot 1, the treatments that stood out were DFs-C5 and DFs416. Considering all lots, for discolorating fungi, the treatments resulted in a mean reduction of $38 \%$ for both combinations tested (DFs-C4 and DFs-C5), and $29 \%$ for both of the best individual treatments (DFs 185 and DFs306). Regarding non-discolorating fungi, the combinations reduced the incidence in $25 \%$, and the DFs 185 and DFs 416 treatments led to a reduction of $30 \%$.
For the B. oryzae transmission assay, no interaction was observed among the three evaluated factors (bacterial treatment $\mathrm{x}$ cultivar $\mathrm{x}$ lot), therefore, the data were presented jointly (Figure 3). The isolated treatments DFs185, DFs223 and DFs306 and the DFs-C5 combination significantly reduced the pathogen transmission from the seeds to the seedlings, varying from 21 to $29 \%$ of efficiency ( $24 \%$ in average). Similarly, there was also no interaction among the evaluated factors for the plant growth analysis, that is, no effect was observed according to the cultivar or lot, and, in that case, only the individual bacterial treatments resulted in a significant plant growth promotion (Table 1). The treatments with DFs185 and DFs306 individually increased the shoot length (26 and 23\% respectively), the root system (respectively 22 and $29 \%$ ) and the seedling total (21 and 25\% respectively).

The assays conducted showed, in general, that bacterial treatments were efficient in different situations, that is, according to the evaluated variable, lot and cultivar used. However, some treatments stood out in several situations, especially DFs 185 , which reduced the incidence of the studied pathogen, as well as of other phytopathogenic fungi, grouped as seed discoloration and non-discoloration, in addition to reducing the disease transmission and promoting plant growth. Additionally, the DFs306 treatment reduced the transmission of B. oryzae and promoted seedling growth, in addition to reducing the incidence of $B$. oryzae and rice discoloration fungi on cultivar BRS Pelota. The studied combinations showed similar or lower performance.

Over 100 fungi species have already been identified on rice seeds up to the moment. However, their inoculum level on the seeds depends on the collecting time, location and cultivar. On the other hand, the position and structure of the seed and the environmental conditions during the seed development also contribute for the establishment of the pathogen population (Ghosh et al., 2018), and its transmission is strongly related to the inoculum level on the seed (Schwanck et al., 2015). Therefore, differences among cultivars and seed lots are expected, which could explain the difference on the efficiency of bacterial treatments.

On the other hand, the biocontrol-pathogen interaction varies according to their isolates. The response is dosedependent according to the pathogen and the biocontrol population, as well as their mechanisms of action. When the mechanism involves induced systemic resistance, once the minimal population is reached, density is no longer primordial; while for competition, it is crucial at all times (Larkin and Fravel, 1999). It is known, for example, that for Pseudomonas, the production of antibiotics (i.e. phenazines) is important to maintain high density and for the constitution of the biofilm on seeds and roots, contributing for their biocontrol ability (De Maeyer et al., 2011). 


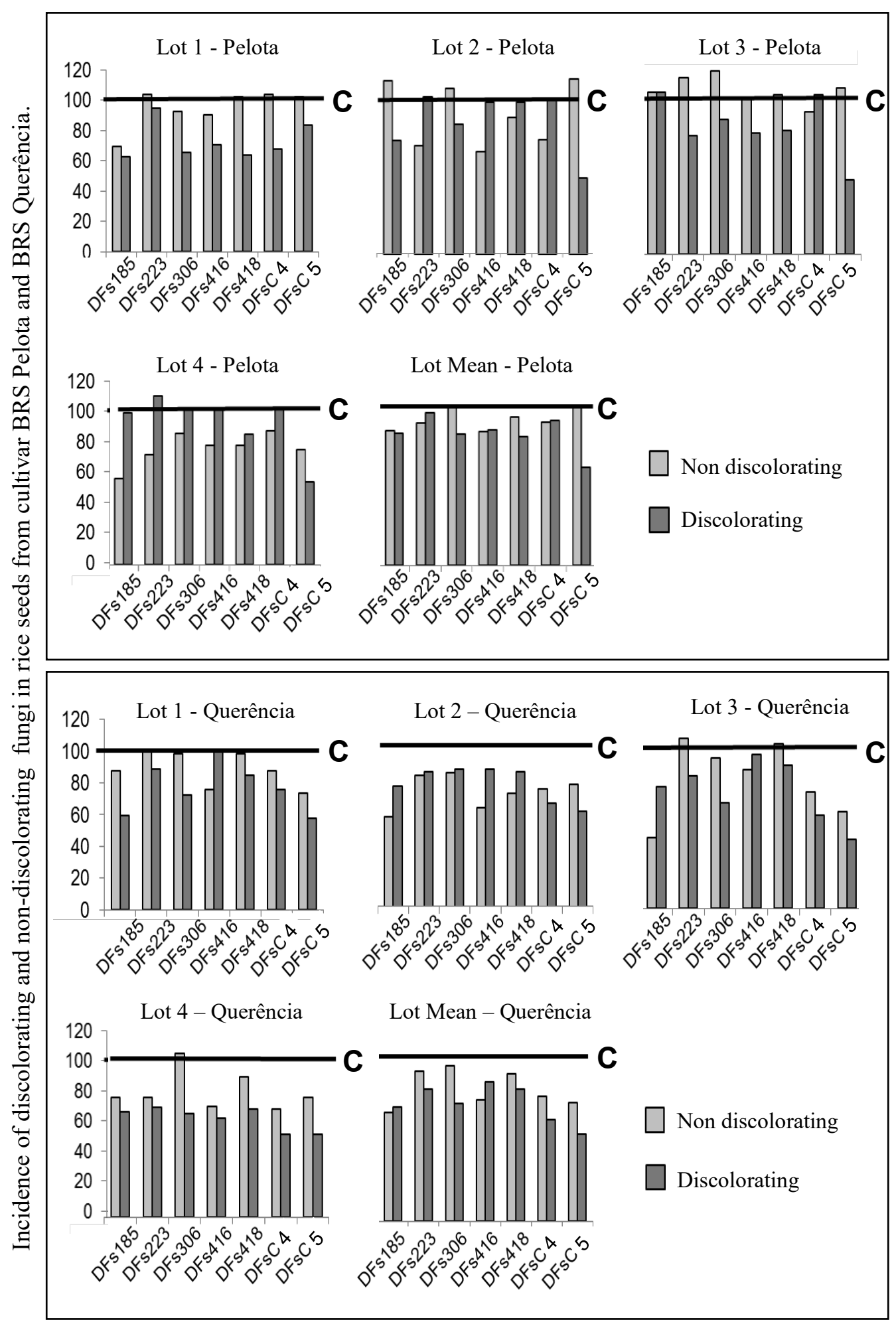

Figure 2. Incidence (\%) of discolorating and non-discolorating fungi in seeds from cultivar BRS Pelota and BRS Querência microbiolized with treatments DFs 185 (Pseudomonas synxantha), DFs 223 (P. fluorescens), DFs 306 (non-identified), DFs416 and DFs418 (Bacillus sp.) and combinations DFS-C4 (185/416/418) and DFs-C5 (306/416/418) using the blotter test method. Control (C) considered as $100 \%$. 


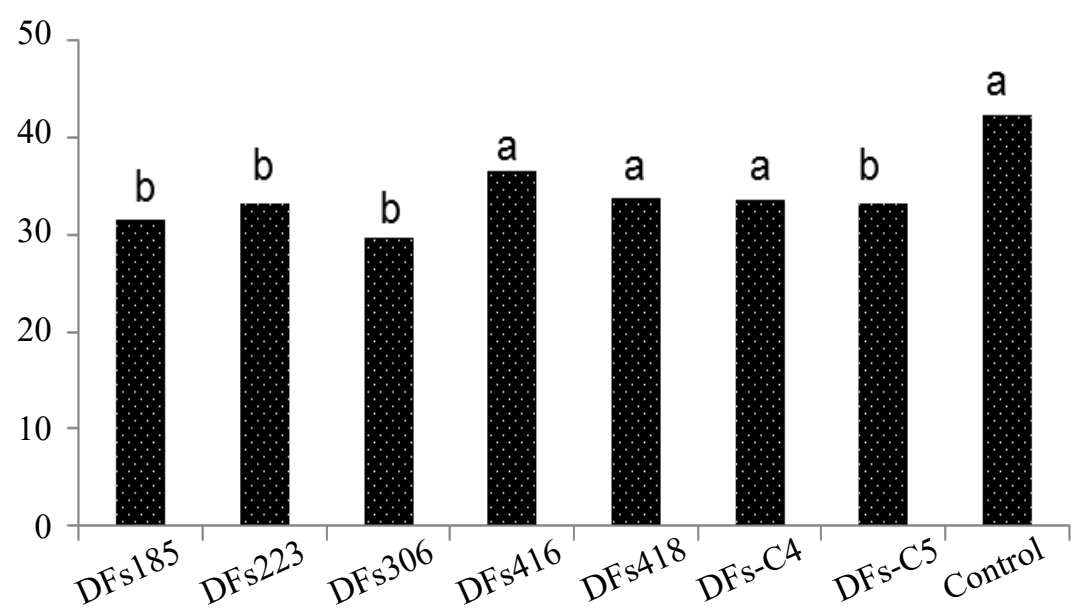

Figure 3. Disease severity index calculated using the Mc Kinney formula according to the brown spot severity scale on rice seedlings from cultivars BRS Pelota and BRS Querência from naturally infested seeds with Bipolaris oryzae, microbiolized with the following treatments: DFs185 (Pseudomonas synxantha), DFs223 (P. fluorescens), DFs 306 (non-identified), DFs416 and DFs418 (Bacillus sp.) and combinations DFs-C4 (185/416/418) and DFs-C5 (306/416/418). Control (C) considered as 100\%. Similar letters are not statistically different according to Tukey's test at $5 \%$ probability.

Thus, the benefits of using biocontrol agents from $B$. oryzae and from other fungi present on seeds through microbiolization with rhizobacteria are clear, with emphasis to isolates DFs185 and DFs306. Biocontrol through the microbiolization of seeds is a feasible method, also in combination with other management techniques, due to its easy application, low cost and lack of environmental residues. The results found by this study corroborate the statement made by Bettiol and Morandi (2009) that the introduction of rhizobacteria on seeds aiming at a reduced pathogen transmission may be a feasible alternative.

This fact has also been evidenced by Moura et al. (2014), who worked with microbiolized rice seeds with the same individual bacterial treatments used on this research and observed a reduction on the B. oryzae transmission by naturally infested/infected seeds to rice seedlings on growth chamber assays. Similarly, studies conducted by Fessehaie and Walcott (2005) showed that, when watermelon (Citrullus lanatus) seeds were microbiolized with an isolate of Acidovorax avenae subsp. avenae or P. fluorescens, a reduction occurred on the transmission to seedlings of the pathogenic bacteria $A$. avenae subsp. citruli, previously inoculated on the seeds. On bean seeds (Phaseolus vulgaris) microbiolized with Xanthomonas axonopodis pv. phaseoli biocontrol bacteria , Corrêa et al. (2008) also observed a reduction on the transmission of Colletotrichum lindemuthianum from naturally infested/ infected seeds to seedlings.

The use of biocontrol combinations, as studied here, is justified by the premise that compatible combinations may intensify the biocontrol effect and/or broaden the spectrum of controlled pathogens, in addition to offering stability in terms of effect under different adverse conditions in the field (Liu et al., 2018). In fact, several studies report such behavior, including for the combination of Pseudomonas and Bacillus isolates (such as the DFs-C4 combination), as

Table 1. Length $(\mathrm{cm})$ and dry biomass $(\mathrm{g})$ of the shoot, root and total of rice seedlings obtained from microbiolized seeds with isolated rhizobacteria and in combinations.

\begin{tabular}{clll}
\hline \multirow{2}{*}{ Treatments } & \multicolumn{3}{c}{ Seedling length } \\
\cline { 2 - 4 } & Shoot & Root & Total \\
\hline DFs185 & $12.17 \mathrm{a}$ & $7.19 \mathrm{a}$ & $19.36 \mathrm{a}$ \\
DFs223 & $11.58 \mathrm{ab}$ & $6.89 \mathrm{ab}$ & $18.43 \mathrm{ab}$ \\
DFs306 & $12.39 \mathrm{a}$ & $7.58 \mathrm{a}$ & $19.97 \mathrm{a}$ \\
DFs416 & $11.12 \mathrm{ab}$ & $6.38 \mathrm{ab}$ & $17.50 \mathrm{ab}$ \\
DFs418 & $11.21 \mathrm{ab}$ & $6.88 \mathrm{ab}$ & $18.07 \mathrm{ab}$ \\
DFs-C4 (185/416/418) & $11.58 \mathrm{ab}$ & $6.29 \mathrm{ab}$ & $17.85 \mathrm{ab}$ \\
DFs-C5 (306/416/418) & $11.53 \mathrm{ab}$ & $6.67 \mathrm{ab}$ & $18.19 \mathrm{ab}$ \\
Control & $10.10 \mathrm{~b}$ & $5.89 \mathrm{~b}$ & $15.99 \mathrm{~b}$ \\
\hline CV(\%) & 19.42 & 20.54 & 17.61 \\
\hline \multicolumn{4}{c}{ Seedling dry biomass } \\
\hline \multirow{2}{*}{ Treatment mean } & Shoot ${ }^{\mathrm{ns}}$ & Root & Total \\
\cline { 2 - 4 } & 0.2166 & 0.0285 & 0.2460 \\
\hline
\end{tabular}

ns- non-significant according to Tukey's test at $5 \%$ of error probability. Values followed by similar letters are not different according to Tukey's test at $5 \%$ of error probability. 
well as the treatment of Setaria italica seeds with a quadruple mix to control blast (P. grisea) in the field (Karthikeyan and Gnanamanickam, 2008) and Brassica campestris seeds with a double combination to control Xanthomonas campestris pv. campestris (Mishra and Arora, 2012).

The data obtained here showed that there was no intensification of the biocontrol effect with the use of combinations. However, this behavior is known, specially for pathogens transmission from seeds to seedlings, both for the fungi and bacteria combination (Bacillus subtillis and Trichoderma harzianum) in relation to Fusarium oxysporum f. sp. ciceris on chickpeas (Hervás et al., 1998), and for the biocontrol bacteria combination in relation to C. lindemuthianum on beans (Corrêa et al., 2008). Additionally, Souza-Júnior et al. (2017), working with the same bacteria used on this research, observed a similar behavior, that is, when bacteria that are individually effective are combined, this does not necessary lead to an increase on the control efficiency.

The treatment of seeds with certain microorganisms has also been used to increase yield, since, in addition to protecting the plants from the attack of pathogens, they may also promote plant growth. Such effect is known for different species (Ahemad and Kibret, 2014), including rice (Lucas et al., 2014; Moura et al., 2014; Souza et al., 2013). Similarly, Soares et al. (2014) reported that rhizobacteria DFs185 improved the physiological performance of rice seeds submitted to low temperatures. Additionally, Soares et al. (2012) observed that the microbiolization of rice seeds with rhizobacteria DFs185, DFs223, DFs306, DFs416 increased the physiological potential of rice seeds with low initial quality, highlighting treatment DFs 185 as a promoting treatment, to be used on rice seeds, since it stimulates the germination of seeds and the emergence of seedlings.

Finally, this study shows greater efficiency of individually applied bacteria than in compatible combinations. In that sense, bacteria DFs185 and DFs306 were efficient across all aspects studied here, that is, they reduced the incidence of the pathogen, as well as its transmission from seeds to seedlings, resulting in increased plant growth. Moura et al. (2014) found similar results when using the same bacteria to microbiolize seeds of lots from two different cultivars than the ones studied here. The authors justified the results obtained due to the diversity of antimicrobial compounds produced by such bacteria, as well as due to their ability to colonize the roots of rice seedlings, attributing the control reached to antibiosis (DFs185) and/or to the induced systemic resistance for both isolates. It is possible that this putative synergic action is the basis for the better performance of bacteria DFs 185 and DFs306 in relation to the combinations, just to use the latter is precisely to combine different compounds produced and, therefore, different mechanisms of action. Additionally, the results of this study associated to those obtained by Moura et al. (2014) indicate a stable effect of bacteria DFs185 and DFs306 when used to microbiolize different rice cultivars.

\section{Conclusions}

The combination of individually efficient biocontrol bacteria did not lead to lower fungi incidence, nor to a reduction on the $B$. oryzae transmission to seedlings or an increase of the initial growth of the seedling. Therefore, such rhizobacteria are more efficient when used individually.

\section{Acknowledgments}

This study was financed in part by the Coordenação de Aperfeiçoamento de Pessoal de Nivel Superior (CAPES) Finance Code AUXPE-PNPD 61623/2010.

\section{References}

AHEMAD, M.; KIBRET, M. Mechanisms and applications of plant growth promoting rhizobacteria: current perspective. Journal of King Saud University - Science, v.26, p.1-20, 2014. http://dx.doi. org/10.1016/j.jksus.2013.05.001

ALFENAS, A.C.; MAFIA, R.G. (Eds.). Métodos em fitopatologia (2a. ed.). Viçosa: Editora UFV, 2016. 516p.

APS. THE AMERICAN PHITOPATOLOGICAL SOCIETY. Temporais > Progresso das doenças epidemiologia de doenças de plantas: aspectos temporais progresso das doenças. http://www. apsnet.org/edcenter/advanced/topics/EpidemiologiaPort/Pages/ Disease\%20Progress.aspx Accessed on jul 29 ${ }^{\text {th }}, 2015$.

BETTIOL, W.; MORANDI, M.A.B. Biocontrole de doenças e plantas: uso e perspectivas. (Ed.) Jaguariúna-SP: Embrapa Meio Ambiente, 2009. 341p. http://www.cnpma.embrapa.br/download/ livro_biocontrole.pdf

BRASIL. Ministério da Agricultura, Pecuária e Abastecimento. Manual de análise sanitária de sementes. Brasília: MAPA/ACS, 2009a. 200p. https://www.abrates.org.br/files/manual-de-analisesanitaria-de-sementes.pdf

BRASIL. Ministério da Agricultura, Pecuária e Abastecimento. Regras para análise de sementes. Ministério da Agricultura, Pecuária e Abastecimento. Secretaria de Defesa Agropecuária. Brasília: MAPA/ACS， 2009b. 395p. file://C:/Users/Usu\%C3\%A1rio/ Downloads/Regras\%20para\%20Analise\%20de\%20Sementes.pdf

CHANDLER, D.; BAILEY, A.S.; TATCHELL, G.M.; DAVIDSON, G.; GREAVES, J.; GRANT, W.P. The development, regulation and use of biopesticides for integrated pest management. Philosophical Transactions of the Royal Society B, v.366, p.1987-1998, 2011. doi:10.1098/rstb.2010.0390 
CONAB. Companhia Nacional de Abastecimento. Acompanhamento de safra brasileira: Sexto levantamento de grãos, safra 2013/2014.http:/www.conab.gov.br/OlalaCMS/uploads/ arquivos/14_03_12_08_41_24_boletim_graos_marco_2014.pdf. Accessed on may $26^{\overline{\mathrm{th}}}, 2015$.

CORRÊA, B.O.; MOURA, A.B.; DENARDIN, N.D.; SOARES, V.N.; SCHÄFER, J.T.; LUDWIG, J. Influência da microbiolização de sementes de feijão sobre a transmissão de Colletotrichum lindemuthianum (Saac. e Magn.). Revista Brasileira de Sementes, v.30, n.2, p.156-163, 2008. http://www.scielo.br/pdf/rbs/v30n2/ a19v30n2.pdf

DE MAEYER, K.; D’AES, J.; HUA, G.K.H.; PERNEEL, M.; VANHAECKE, L.; NOPPE, H.; HOFTE, M. N-Acylhomoserine lactone quorum-sensing signalling in antagonistic phenazineproducing Pseudomonas isolates from the red cocoyam rhizosphere. Microbiology, v.157, p.459-472, 2011. http://www.microbiologyresearch.org/docserver/fulltext/micro/157/2/459.pdf?expires $=1532468986 \& \mathrm{id}=\mathrm{id} \&$ accname $=$ guest $\&$ checksum $=$ C70AC4CEA0C7A1082677EDAD5C9E75D2

FAGUNDES, P.R.R.; MAGALHÃES JÚNIOR, A.M.; FRANCO, D.F.; RANGEL, P.H.N.; CUTRIN, V.S.; NEVES, P.C.F.; MOURANETO, F.P.; SOARES, R.C. BRS Querência: precocidade, produtividade e qualidade para a orizicultura gaúcha. Embrapa Clima Temperado: Pelotas, 2005. 6p. (Circular Técnica 47) http:// www.infoteca.cnptia.embrapa.br/infoteca/bitstream/doc/746114/1/ CircT47.pdf

FARIAS, C.R.J.; AFONSO, A.P.S.; PIEROBOM, C.R.; DEL PONTE, E.M. Regional survey and identification of Bipolaris spp. associated with rice seeds in Rio Grande do Sul State, Brazil. Ciência Rural, v.41, n.3, p.369-372, 2011. http://www.scielo.br/pdf/ cr/v41n3/a882cr4060.pdf

FESSEHAIE, A.; WALCOTT, R.R. Biological control to protect watermelon blossoms and seed from infection by Acidovorax avenae subsp. citrulli. Phytopathology, v.95, n.4, p.413-419, 2005. http:// apsjournals.apsnet.org/doi/pdf/10.1094/PHYTO-95-0413

GHOSH, T.; BISWAS, M.K.; GUIN, C.; ROY, P.; AIKAT, K. A review on seed borne mycoflora associated with different cereal crop seeds and their management. Plant Cell Biotechnology and Molecular Biology, v.19, n.3, p.107-117, 2018.http://www.ikpress. org/abstract/6865

HERVÁS, A.; LANDA, B.; DATNOFF, L.E.R.; JIMÉNEZ-DÍAZ, $M$. Effects of commercial and indigenous microorganisms on Fusarium wilt development in chickpea. Biological Control, v.13, p.166-176, 1998.

KARTHIKEYAN, V.; GNANAMANICKAM, S.S. Biological control of Setaria blast (Magnaporthe grisea) with bacterial strains. Crop Protection, v.27, n.2, p.263-267, 2008. https://www. sciencedirect.com/science/article/pii/S0261219407001457

LARKIN, R.P.; FRAVEL, D.R. Mechanisms of action and doseresponse relationships governing biological control of Fusarium wilt of tomato by nonpathogenic Fusarium spp. Phytopathology, v.89, n.12, p.1152-1161, 1999.
LIU, K.; MCINROY, J.A.; HU, C.H.; KLOEPPER, J.W. Mixtures of plant-growth-promoting rhizobacteria enhance biological control of multiple plant diseases and plant-growth promotion in the presence of pathogens. Plant Disease, v.102, n.1, p.67-72, 2018. https://doi. org/10.1094/PDIS-04-17-0478-RE

LUCAS, J.A.; GARCÍA-CRISTOBAL, J.; BONILLA, A.; RAMOS, B.; GUTIERREZ-MAÑERO, J. Beneficial rhizobacteria from rice rhizosphere confers high protection against biotic and abiotic stress inducing systemic resistance in rice seedlings. Plant Physiology and Biochemistry, v.82, p.44- 53, 2014. http://dx.doi.org/10.1094/ PHYTO-98-6-0666

LUDWIG, J.; MOURA, A.B.; SANTOS, A.S.; RIBEIRO, A.S. Biocontrole da mancha parda e da escaldadura em arroz irrigado, pela microbiolização de sementes. Tropical Plant Pathology, v.34, n.5, p.322-328, 2009. http://www.scielo.br/pdf/tpp/v34n5/v34n5a05.pdf

LUDWIG, J.; MOURA, A.B.; GOMES, C.B. Potential of microbiolization of rice seeds with rhizobacteria for root-knot nematode biocontrol. Tropical Plant Pathology, v.38, n.3, p.264268, 2013. http://www.scielo.br/pdf/tpp/v38n3/tpp2012-0005.pdf

MISHRA, S.; ARORA, N.K. Evaluation of rhizospheric Pseudomonas and Bacillus as biocontrol tool for Xanthomonas campestris pv. campestris. World Journal Microbiology and Biotechnology, v.28, p.693-702, 2012. https://link.springer.com/ content/pdf/10.1007\%2Fs11274-011-0865-5.pdf

MOURA, A.B.; LUDWIG. J.; SANTOS, A.G.; SCHAFER, J.T.; SOARES, V.N.; CORRÊA, B.O. Biocontrol and seed transmission of Bipolaris oryzae and Gerlachia oryzae to rice seedlings. Journal of Seed Science, v.36, n.4, p.407-412, 2014. http:/www.scielo.br/ pdf/jss/v36n4/a04v36n4.pdf

NUNES, C.D.M.; RIBEIRO, A.S.; TERRES, A.L.S. Principais doenças em arroz irrigado e seu controle. In: GOMES, A.S.; MAGAlHÃes JR, A.M. (Ed.) Arroz irrigado no sul do Brasil. Brasília: Embrapa Informação Tecnológica, 2004. p.579-622.

SCHWANCK, A.A.; MENESES, P.R.; FARIAS, C.R.J.; FUNCK, G.R.D.; MAIA, A.H.N.; DEL PONTE, E.M. Bipolaris oryzae seed borne inoculum and brown spot epidemics in the subtropical lowland rice-growing region of Brazil. European Journal of Plant Pathology, v.142, n.4, p.875-885, 2015. https://link-springer-com. ez66.periodicos.capes.gov.br/journal/10658/142/4/page/1

SOARES, V.N.; TILLMANN, M.A.A.; MOURA, A.B.; ZANATTA, Z.G.C.N. Physiological potential of rice seeds treated with rhizobacteria or the insecticide thiamethoxam. Revista Brasileira de Sementes, v.34, n.4, p.563-572, 2012. http://www.scielo.br/scielo. php?pid=S0101-31222012000400006\&script=sci_arttext\&tlng=en

SOARES, V.N.; RADKE, A.K.; TILLMANN, M.A.A.; MOURA, A.B.; SCHUCH, L.O.B. Physiological performance of rice seeds treated with thiamethoxam or rhizobacteria under different temperatures. Journal of Seed Science, v.36, n.2, p.186-193, 2014. http://www.scielo.br/pdf/jss/v36n2/v36n2a07.pdf

SOSBAI. Sociedade Sul-Brasileira de Arroz Irrigado. Arroz irrigado: recomendações técnicas da pesquisa para o Sul do Brasil. Itajaí, SC: SOSBAI, 2012. 179p.http://www.irga.rs.gov.br/ upload/20140724143610boletim_arroz_irrigado_2012.pdf 
SOUZA-JÚNIOR, I.T.; MOURA, A.B.; SCHAFER, J.T.; CORRÊA, B.O.; GOMES, C.B. Biocontrole da queima-das-bainhas e do nematoide-das-galhas e promoção de crescimento de plantas de arroz por rizobactérias. Pesquisa Agropecuária Brasileira, v.45, n.11, p.1259-1267, 2010. http://www.scielo.br/pdf/pab/v45n11/05.pdf

SOUZA-JÚNIOR, I.T.; SCHAFER, J.T.; CORRÊA, B.O.; FUNCK, G.D.; MOURA, A.B. Expansion of the biocontrol spectrum of foliar diseases in rice with combinations of rhizobacteria. Revista Ciência Agronômica, v.48, n.3, p.513-522, 2017. http://dx.doi. org/10.5935/1806-6690.20170060
SOUZA, R.; BENEDUZI, A.; AMBROSINI, A.; BESCHOREN, C.P.; MEYER, J.; VARGAS, L. K.; SCHOENFELD, R.; PASSAGLIA, L.M.P. The effect of plant growth-promoting rhizobacteria on the growth of rice (Oryza sativa L.) cropped in southern Brazilian fields. Plant Soil, v.366, p.585-603, 2013.http://link.springer.com/ article/10.1007/s11104-012-1430-1

XU, X.M.; JEFFRIES, P.; PAUTASSO, M.; JEGER, M.J. Combined use of biocontrol agents to manage plant diseases in theory and practice. Phytopathology, v.101, n.9, p.1024-1031, 2011. http:// apsjournals.apsnet.org/doi/pdfplus/10.1094/PHYTO-08-10-0216 